9. Оноприйчук Б. С. Основные цели и этапы адаптации персонала в организации. Социальные науки. 2014. № 1. С. 11.

10. Gebhard J. EFL learners studying abroad: Challenges and strategies. Asian EFL Journal. 2013. 15 (2). P. $155-182$.

11. Internationally mobile students, Global, 20112017. Migration Data Portal. URL: https://migration dataportal.org/themes/international-students (дата звернення: 10.05.2020).

12. Top 20 countries for international students. The Guardian. URL: https://www.theguardian.com/higher- -education-network/blog/2014/jul/17/top-20-countries-international-students (дата звернення: 07.05.2020).

13. Zinonos N. Prospects of Using the Augmented Reality for Training Foreign Students at the Preparatory Departments of Universities in Ukraine. Augmented Reality in Education : Proceedings of the 1st International Workshop (AREdu 2018), Kryvyi Rih, Ukraine, 2 October, 2018. P. 87-92. URL: http:// ceur-ws.org/Vol-2257/paper10.pdf (дата звернення: 05.05.2020).

Дата надходження до редакиї: 14.05.2020 p.
УДК 378.091.212:37:316.64

DOI: $10.37026 / 2520-6427-2020-103-3-97-100$

\section{Сергій ШАРОВ,}

кандидат педагогічних наук,

доцент кафедри української та зарубіжної літератури Мелітопольського державного педагогічного університету імені Богдана Хмельницького

\title{
СТРУКТУРА ТА ЗМІСТ СОЦАЛЬНОЇ КОМПЕТЕНТНОСТІ СТУДЕНТІВ ПЕДАГОГІЧНОГО УНІВЕРСИТЕТУ
}

У статті розглянуто та систематизовано різні підходи до визначення структури соиіальноїкомпетентності учнів та студентів. Здійснено аналіз структури $i$ змісту соиіальної компетентності студентів педагогічного університету, зокрема ї̈ окреслено як багатокомпонентну характеристику особистості, ше дозволяє комфортно взаємодіяти із соиіальним середовищем та уникати конфліктів. Схарактеризовано компоненти соиіальної компетентності, представлені низкою дослідників, доведено, щчо соиіальна компетентність студентів педагогічного університету має певні особливості у зв'язку зі специирічністю та унікальністю обраної професії. Зазначено, щзо соиіальна компетентність студентів педагогічного університету включає такі компоненти, як: когнітивно-ціннісний (наявність соиіальних уявлень, изіннісних орієнтацій); емоційно-мотиваційний (наявність мотивації на розвиток власної соиіальної компетентності); операційно-діяльнісний (володіння вміннями конструктивної взаємодї із зовнішнім середовищем); рефлексивний (здатність адекватно реагувати на виниклі сочіальні ситуаціï).

Ключові слова: суспільство, компетентність, соичіалізація, здобувачі вищої освіти, структура.

В статье рассмотреньл и систематизированы различные подходы к определению структуры сочииальной компетентности учашихся и студентов. Осуществлен анализ структуры и содержания соџиальной компетентности студентов педагогического университета, в частности она определена как многокомпонентная характеристика личности, позволяющая комфортно взаимодействовать с соичальной средой и избегать конфликтов. Охарактеризовань компоненты сочииальной компетентности, представленные рядом исследователей, доказано, что соииальная компетентность студентов педагогического университета имеет свои особенности вследствие специфики и уникальности выбранной профессии. Отмечено, что сочиальна компетентность студентов педагогического университета включает такие компоненты, как: когнитивно-иенностный (наличие социальных представлений, цзенностных ориентаицй); эмоционально-мотивационный (наличие мотивации на развитие собственной социальной компетентности); операционно-деятельностный (владение умениями конструктивного взаимодействия с внешней средой); рефлексивный (способность адекватно реагировать на возникиие социиальные ситуации).

Ключевые слова: общество, компетентность, сочииализация, студенты, структура.

In this article different approaches to determining the structure of social competence of students and students are considered and systematized. Also we analyze structure and content of social competence of students of pedagogical university. We must noticed that social competence is one of the major competences of the modern individual, who is responsible for the effective life in society and constructive interaction with different people, social groups and institutions. In article author gives definition of social competence, its importance for the development of personality. Author make conclusion that it is a multicomponent characteristic of a person, 
which allows comfortably interact with the social environment and avoid conflicts. Presented characteristics of social competence components of different researchers. It is revealed that the structure of social competence contains components responsible for the presence in the personality some knowledge (knowledge, cognitive, sociological components), motivation (personaly-motivational, motivational components), social values, ability to evaluate events and phenomena (personality-value, value - dispositional components), behavior and activity (activity, behavioral, communicative components), reflections (reflective component), performance of certain social roles (status-role component). We must say that the structure includes both simple components (activity, personality, evaluation), and complex components (personality-motivational, communicative-behavioral). It is noted that the social competence of the students has its peculiarities due to the specificity and uniqueness of the chosen profession. The future teacher must learn to be accountable for his or her own actions, to work on a professional level, and to encourage others to achieve a social goal. It is revealed that social competence contains cognitive-value (presence of social representations, value orientations), emotional-motivational (presence of motivation for the development of one's own social competence), operational-activity (possession of constructive interaction skills with the external environment), reflexive ability to react for emerged social situations). Emphasise on the social competencies that a future teacher of Ukrainian language and literature must possess.

Key words: society, competence, socialization, Higher Education Applicants, structure.

Постановка проблеми. Необхідність підготовки молоді до життєдіяльності в сучасних динамічних умовах інформаційного суспільства та євроінтеграційних процесів зумовлює формування та розвиток у неї відповідних компетентностей. Особливо це стосується здобувачів вищої освіти, які повинні постійно розширювати діапазон своїх можливостей та здатностей задля підвищення власної конкурентоспроможності на ринку праці. Зважаючи на це, крім формування та розвитку фахових компетентностей, майбутні педагоги повинні опанувати навичками комфортного перебування в соціумі, уникнення та вирішення конфліктів тощо.

За ефективну та активну життєдіяльність у суспільстві, конструктивну взаємодію з іншими людьми та різними соціальними групами відповідає соціальна компетентність. Рівень ії розвиненості впливає на процес соціалізації особистості, формування в неї життєвих позицій, виконання професійних обов'язків та соціальних ролей. За своєю сутністю соціальна компетентність має внутрішню структуру та складається з відповідних компонентів, аналіз яких, разом $з$ іншими питаннями, що неабияк пов'язані із соціальною компетентністю, ми пропонуємо розглянути у нашому дослідженні.

Аналіз наукових досліджень і публікацій. Дослідженням питань формування соціальної компетентності займалися чимало як вітчизняних, так i зарубіжних науковців. Так, структуру соціальної компетентності учнів досліджували Н. Даценко, М. Докторович, Т. Смагіна, В. Шахрай та ін., а соціальну компетентність здобувачів вищої освіти та iii структуру - С. Бекіров, Н. Борбич, I. Зарубінська, T. Качалова, С. Краснокутська, С. Остапенко та ін. Незважаючи на викладене вище, варто зауважити, що різні підходи до вивчення структури соціальної компетентності, а також особливість професії вчителя як носія соціального досвіду актуалізує потребу в уточненні структури соціальної компетентності студентів педагогічних університетів.

Мета статті - здійснити аналіз різних підходів до визначення структури соціальної компетентності здобувачів освіти, висвітлити власний погляд на структуру соціальної компетентності студентів педагогічного університету.

Виклад основного матеріалу. Сьогодні компетентнісний підхід $є$ однією із головних парадигм сучасної системи освіти, що впроваджені в освітню діяльність закладів освіти різних рівнів. Окреслена тенденція $є$ цілком закономірним явищем та зумовлена необхідністю модернізації освіти, інтеграцією України у європейський освітній простір, інтернаціоналізацією та глобалізацією освітньої політики тощо.

У зв'язку з цим компетентність можна охарактеризувати як інтегративне та динамічне утворення зі складною структурою, що включає знання, вміння, ціннісні орієнтації, мотиви особистості, що пов'язані 3 іiі діяльністю в певній сфері. Чимала низка компетентностей дозволяє особистості провадити професійну та навчальну діяльність, а також самореалізуватися в житті [7].

У сучасних умовах фахівець повинен, крім розвинутих професійних якостей, уміти конструктивно взаємодіяти $з$ іншими людьми, групами людей, різними соціальними інститутами, уникати та ефективно вирішувати конфлікти, тобто, за компетентнісним підходом, це означає мати розвинуту соціальну компетентність, яка тлумачиться як складна, багатокомпонентна характеристика особистості, що дозволяє комфортно взаємодіяти із соціальним довкіллям [4, с. 147], налагоджувати контакти 3 різноманітними людьми та групами людей, активно взаємодіяти із соціумом, брати участь у соціально-значущих проєктах [5].

Означена вище педагогічна категорія є однією 3 ключових компетентностей сучасного фахівця та містить масив знань, умінь, здібностей, способів діяльності, що дозволяють людині комфортно відчувати себе в суспільному повсякденні, на роботі, під час спілкування тощо [10, с. 201]. Крім того, в умовах сучасного інформаційного суспільства, коли комунікація та спілкування із соціумом зазвичай відбувається за допомогою засобів інформаційно-комунікаційних технологій та різноманітних цифрових пристроїв [9, с. 212], соціальна компетентність допоможе досягти конструктивного діалогу під час вирішення буденних та виробничих задач, а розкриття структури соціальної компетентності та іiї змісту сприятиме з'ясуванню ефективних механізмів соціальної адаптації особистості в сучасних мінливих умовах.

До структури соціальної компетентності науковці відносять такі компоненти:

- когнітивний, емоційно-мотиваційний, особистісно-ціннісний, комунікативно-поведінковий [3, с. 10];

- ціннісно-мотиваційний, когнітивний, діяльнісний, рефлексивний, особистісний [5];

- статусно-рольовий, ціннісно-диспозиційний, комунікативний $[11$, с. 15$]$;

- мотиваційно-особистісний, партисипативно-діяльнісний, імплементаційно-управлінський, рефлексивний $[6$, с. 188$]$;

- знаннєвий, ціннісний, поведінковий [1, с. 20].

Схарактеризуємо їх більш докладно.

Так, Н. Даценко у структурі соціальної компетентності учнів виокремлює такі основні компоненти, як: когнітивний - передбачає наявність сукупність 
знань про себе, соціальну дійсність, норми та правила поведінки у суспільстві; емоиійно-мотивачійний - передбачає наявність здатностей до розуміння внутрішніх і зовнішніх емоцій та станів, мотивації до саморозвитку; особистісно-иіннісний - характеризується наявністю таких рис, як толерантність, повага до оточуючих, відчуття власної гідності, принциповість); комунікативно-поведінковий - характеризується наявністю певного соціального досвіду, виконанням різноманітних соціальних ролей, адекватного реагування на різні соціальні ситуації [3, с. 10].

Зі свого боку дослідниця В. Шахрай до структури соціальної компетентності учнів відносить такі компоненти, як: статусно-рольовий - передбачає усвідомлення сутності соціальних ролей у суспільстві, адекватний вибір та творче виконання соціальних ролей; иіннісно-диспозиційний - передбачає наявність розвинутих соціально значущих потреб, цінностей, настанов; комунікативний - передбачає наявність у людини соціального інтелекту, здатності до вирішення конкретних соціальних ситуацій $[11$, с. 15].

T. Качалова до структури соціальної компетентності студентів відносить такі компоненти:

мотивачійно-особистісний - передбачає збагачення соціального досвіду, пізнавально-оціночну діяльність, соціальну спрямованість особистості; nартисипативно-діяльнісний - передбачає наявність соціальної активності, відповідних умінь, навичок; імплементаиійно-управлінський - передбачає наявність соціально-прогностичних умінь, здатність до самореалізації у соціальній сфері; рефлексивний - передбачає вміння до самоаналізу соціальної діяльності, саморозвиток особистості [6, с. 189].

С. Бекіров до структури соціальної компетентності майбутніх учителів відносить такі компоненти: знаннєвий - передбачає наявність знань про суспільство та закони його розвитку, способи вирішення конфліктних ситуацій; ціннісний - передбачає наявність таких характеристик особистості, як повага до інших, толерантність, соціальна відповідальність; поведінковий - передбачає наявність умінь до визначення цілей та ефективних стратегій взаємодії та комунікації, виконання різних соціальних ролей, уникнення та вирішення конфліктів [1, с. 20].

Аналіз досліджень науковців щодо структури соціальної компетентності наводимо в таблиці.

Таблиия

Структура соціальної компетентності у дослідженнях науковців

\begin{tabular}{|c|c|c|c|c|}
\hline Дослідники & Компонент № 1 & Компонент № 2 & Компонент № 3 & Компонент № 4 \\
\hline Даценко Н. [3] & когнітивний & $\begin{array}{c}\text { емоційно- } \\
\text { мотиваційний }\end{array}$ & $\begin{array}{l}\text { особистісно- } \\
\text { ціннісний }\end{array}$ & $\begin{array}{c}\text { комунікативно- } \\
\text { поведінковий }\end{array}$ \\
\hline Зарубінська I. [5] & когнітивний & $\begin{array}{c}\text { ціннісно- } \\
\text { мотиваційний }\end{array}$ & особистісний & $\begin{array}{l}\text { діяльнісний, } \\
\text { рефлексивний }\end{array}$ \\
\hline Бекіров С. [1] & знаннєвий & & ціннісний & поведінковий \\
\hline Шахрай В. [11] & & $\begin{array}{c}\text { ціннісно- } \\
\text { диспозиційний }\end{array}$ & статусно-рольовий & комунікативний \\
\hline Качалова Т. [6] & & $\begin{array}{l}\text { мотиваційно- } \\
\text { особистісний }\end{array}$ & $\begin{array}{c}\text { імплементаційно- } \\
\text { управлінський }\end{array}$ & $\begin{array}{c}\text { партисипативно- } \\
\text { діяльнісний, } \\
\text { рефлексивний }\end{array}$ \\
\hline
\end{tabular}

Порівнюючи дані, наведені в таблиці, зауважимо, що найбільш характерними структурними складовими соціальної компетентності є такі компоненти, як когнітивний, ціннісний, мотиваційний, емоційний, поведінковий, діяльнісний, рефлексивний та комунікативний. Окремі з них, наприклад, мотиваційно-ціннісний, емоційно-мотиваційний, поведінково-діяльнісний та ін., були поєднані дослідниками у складені структури, що є цілком імовірно, оскільки вони доречно доповнюють один одного.

Слід зазначити, що соціальна компетентність студентів педагогічного університету має певні особливості, пов'язані передусім зі специфікою та унікальністю обраної професії, оскільки вчитель у процесі своєї професійної діяльності повинен передавати свої знання та вміння учням, навчати їх орієнтуватися в надзвичайно мінливому сучасному суспільстві. При цьому заклад освіти $є$ тим важливим осередком, що індивідуалізує процес соціалізації молоді [8, с. 188].

Ураховуючи дослідження науковців щодо структури соціальної компетентності, до компонентів соціальної компетентності студентів педагогічних університетів ми відносимо такі: когнітивно-ціннісний (наявність соціальних уявлень, ціннісних орієнтації); емоиійно-мотиваиійний (наявність мотивації на розвиток власної соціальної компетентності та конструктивну взаємодію із соціумом, система засобів емоційного реагування на різні ситуацій); операиійно-діяльнісний (володіння необхідними вміннями та способами конструктивної взаємодії із зовнішнім середовищем); рефлексивний (здатність аналізувати власну діяльність із точки зору соціальної взаємодії із зовнішнім середовищем, наявність здатності адекватного реагування на виниклі ситуації).

Н. Борбич у зв'язку з цим звертає увагу на те, що в умовах навчально-виховного процесу педагогічного коледжу майбутні учителі повинні розвинути здатність дослухатися до думки інших, брати на себе відповідальність за власні дії, спонукати інших та працювати самому задля досягнення мети. Крім того, в студентів упродовж навчання повинні розвинутися такі риси особистості, як оригінальність та самостійність мислення, адекватна самооцінка та оцінка можливостей членів колективу тощо [2, с. 68$]$.

Щодо соціальної компетентності студентів педагогічного університету, зокрема майбутніх учителів української мови і літератури, то вона передбачає вміння застосовувати ефективні способи взаємодії 3 колегами та учнями відповідно до ситуації, здатність до прогнозування проблемних ситуацій $з$ метою їх вчасного уникнення та позитивного вирішення; використання різноманітних словесно-наочних та емоційних засобів задля досягнення поставленої мети; толерантне відношення до співрозмовників, уникнення критики; критичне ставлення до себе та своєї поведінки у процесі виконання професійної діяльності. 
Висновки. Отже, соціальна компетентність є однією з ключових компетентностей сучасної особистості, адже відповідає за ефективну життєдіяльність у суспільстві та конструктивну взаємодію з різними людьми, соціальними групами, інституціями. Структура соціальної компетентності передбачає низку компонентів, пов'язаних із соціальними знаннями, мотивацією, оцінкою соціальних ситуації, відповідною діяльністю та поведінкою. Соціальна компетентність студентів педагогічного університету є важливою складовою їхнього професійного становлення та передбачає у своїй структурі такі основні компоненти, як когнітивно-ціннісний, емоційно-мотиваційний, операційно-діяльнісний та рефлексивний.

Подальші наші наукові дослідження плануємо спрямувати на визначення критеріїв сформованості компонентів соціальної компетентності студентів педагогічних університетів.

\section{СПИСОК ВИКОРИСТАНОЇ ЛІТЕРАТУРИ}

1. Бекиров С. Н. Формирование компонентов социальной компетентности будущих педагогов в процессе их профессиональной подготовке в вузе. Проблемы современного педагогического образования. 2017. № 56-2. С. 16-22.

2. Борбич Н. Формування соціальної компетентності студентів педагогічних коледжів як соціально-педагогічна проблема. Проблеми підготовки сучасного вчителя. 2014. № 10 (1). С. 166-170.

3. Даценко Н. Про структуру соціальної компетентності учнів. Вісник Київського національного університету імені Тараса Шевченка. 2012. № 6. С. 8-10. (Серія «Психологія. Педагогіка. Соціальна робота»).

4. Докторович М. Соціальна компетентність як наукова проблема. Психологія $і$ суспільство. 2009. № 3 (37). C. 144-147.
5. Зарубінська I. Б. Проблема діагностики соціальної компетентності студентів вищих навчальних закладів. Інформаційні технологї $i$ засоби навчання. 2009. № 5 (13). URL: https://journal.iitta.gov.ua/ index.php/itlt/article/view/189/175 (дата звернення: 17.04.2020).

6. Качалова Т. Г. Структурно-функціональні компоненти дидактичної моделі формування соціальної компетентності студентів. Педагогіка вищої та середньої школи. 2014. № 43. С. 186-189.

7. Концепція «Нова українська школа». URL: https://www.kmu.gov.ua/storage/app/media/reforms/ ukrainska-shkola-compressed.pdf (дата звернення: 17.04.2020).

8. Москальова Л. Ю. Соціально-педагогічне проектування культурно-освітнього простору дітей та молоді в освітніх закладах: загальні положення. $\mathrm{Ha}$ уковий вісник Мелітопольського державного педагогічного університету. 2013. № 2. С. 187-190. (Серія «Педагогіка»).

9. Олексенко Р. І. Філософія розвитку інформаційного суспільства в епоху глобалізації. Гілея. 2015. № 38. C. 229-232.

10. Шаров С. В. Дефінітивний аналіз і сутність соціальної компетентності. Науковий часопис національного педагогічного університету імені М. П. Драгоманова. 2019. Серія 5 «Педагогічні науки: реалї та перспективи». Вип. 66. С. 200-203.

11. Шахрай В. М. Теоретико-методичні засади формування соціальної компетентності учнів основної і старшої школи засобами театрального мистецтва : автореф. дис. ... д-ра пед. наук : $13.00 .05 ; 13.00 .07$. Київ : Інститут проблем виховання НАПН України. 2016. 46 с.

Дата надходження до редакиіï: 25.05.2020 p.

Інна ШПИЧАК, кандидат педагогічних наук, стариий викладач кафедри педагогіки, психології та корекційної освіти Рівненського ОІППО

\section{МОТИВАЦІЯ ПРОФЕСІЙНОГО ЗРОСТАННЯ ПЕДАГОГІВ В УМОВАХ НОВОЇ УКРАЇНСЬКОЇ ШКОЛИ}

\footnotetext{
У статті висвітлено особливості формування мотивації педагогів до професійного зростання в умовах Нової украӥнської школи. Розкрито поняття «мотивачія» та «професійна мотивачія». Визначено умови, щзо сприяють мотивачї до професійного зростання вчителів в умовах змін та реформування освіти. Запропоновано діагностичні методики для визначення мотиваційної готовності педагогів до здійснення інновачійної діяльності.
}

Ключові слова: мотивація, професійне зростання, особистість педагога, Нова украӥнська школа.

В статье освещены особенности формирования мотивации педагогов к профессиональному росту в условиях Новой украинской школы. Раскрыто понятия «мотиваџия» и «профессиональная мотивация». Определень условия, способствующие мотиващии $\kappa$ профессиональному росту учителей в условиях 